\title{
Effect of smoking on the association of HHEX (rs5015480) with diabetes among Korean women and heavy smoking men
}

\author{
Jae Woong Sull ${ }^{*}$ D, Tae Yong Lee ${ }^{2}$ and Sun Ha Jee ${ }^{3}$
}

\begin{abstract}
Background: Several genome-wide association studies (GWAS) for serum fasting glucose levels have reported HHEX as possibly causal. The objective of this study was to examine the joint effect of smoking on the association of diabetes with the HHEX rs5015480 polymorphism among Korean subjects.

Methods: This replication study included a total of 4240 individuals, and multivariate linear regression and multiple logistic regression models were used. We examined the combined effect of smoking on the relationship between HHEX rs5015480 and diabetes.

Results: The rs5015480 SNP in the HHEX gene was related to the mean FBS level (effect per allele, $1.572 \mathrm{mg} / \mathrm{dL}$, $p=0.0122$ ). Females with the CC genotype had a 2.68 times higher (range, 1.05-6.82 times) risk of diabetes than those with the $T / T C$ genotype. Although the association was stronger in female subjects $(\mathrm{OR}, 4.46 ; 95 \% \mathrm{Cl}, 1.15-17.3$, $p=0.0304)$ among healthy individuals $(N=2461)$, the association between HHEX and diabetes was much stronger in male heavy smokers $(\mathrm{OR}, 4.03 ; 95 \% \mathrm{Cl}, 1.19-13.6, p=0.0247)$ than in nonsmokers $(p=0.9709)$ and ex-smokers $(p=0.2399)$. The interaction of smoking was also statistically significant ( $P$ for interaction $=0.0182$ ).
\end{abstract}

Conclusions: This study clearly demonstrates that a genetic variant in HHEX influences fasting glucose levels in Korean women and male heavy smokers.

Keywords: Fasting glucose, HHEX, Polymorphisms

\section{Background}

The serum fasting glucose level is a basic indicator of diabetes [1], and several genome-wide association studies (GWAS) examining type 2 diabetes have reported that the hematopoietically expressed homeobox (HHEX) (MIM 604420) gene is a candidate causal gene [2, 3].

Recent studies have shown that the HHEX rs5015480 SNP was related to serum fasting glucose levels or type 2 diabetes [4-9]. In a recent meta-analysis, the rs5015480 SNP was associated with fasting glucose $(p=0.015)$ [4]. Another recent study in the Greek-Cypriot population also reported that the rs5015480 SNP was related to type 2 diabetes $(p=0.002)$ [6]. Several other studies in Chinese population reported that the rs5015480 SNP was related

\footnotetext{
* Correspondence: jsull@eulji.ac.kr

${ }^{1}$ Department of Biomedical Laboratory Science, College of Health Sciences,

Eulji University, Seongnam, South Korea

Full list of author information is available at the end of the article
}

to type 2 diabetes [7-9]. A study in Korean populations reported that the rs5015480 SNP in HHEX was related with diabetes [10]. The HHEX gene has also been linked with fetal cardiac development [11]. A Chinese study also reported that HHEX rs5015480 was associated with diabetes and cardiovascular risk [12]. However, several other studies reported that rs5015480 was not related to type 2 diabetes [13, 14]. Previous studies did not investigate the relationship between rs5015480 and type 2 diabetes considering smoking status.

Therefore, the objective of this study was to examine the joint effect of smoking on the association of diabetes with the HHEX rs5015480 polymorphism among Korean subjects. The relationship between the HHEX rs5015480 polymorphism and cardiovascular disease was also examined.

(c) The Author(s). 2018 Open Access This article is distributed under the terms of the Creative Commons Attribution 4.0 International License (http://creativecommons.org/licenses/by/4.0/), which permits unrestricted use, distribution, and 
Table 1 General characteristics of the study population

\begin{tabular}{|c|c|c|c|c|}
\hline \multicolumn{2}{|l|}{ Subjects } & All & Men & Women \\
\hline \multirow{2}{*}{\multicolumn{2}{|c|}{$N$}} & 4240 & 2887 & 1353 \\
\hline & & Mean \pm SD & Mean \pm SD & Mean $\pm S D$ \\
\hline \multicolumn{2}{|l|}{ Age, year } & $52.2 \pm 10.2$ & $51.9 \pm 10.2$ & $52.7 \pm 10.2$ \\
\hline \multicolumn{2}{|c|}{ Waist circumference, $\mathrm{cm}$} & $84.1 \pm 9.0$ & $87.1 \pm 7.6$ & $78.6 \pm 8.7$ \\
\hline \multicolumn{2}{|c|}{ Body mass index, $\mathrm{kg} / \mathrm{m}^{2}$} & $24.4 \pm 2.9$ & $24.8 \pm 2.7$ & $23.5 \pm 3.2$ \\
\hline \multicolumn{2}{|c|}{ Fasting blood sugar, mg/Dl } & $97.0 \pm 22.7$ & $98.9 \pm 24.1$ & $93.1 \pm 18.7$ \\
\hline \multicolumn{2}{|c|}{$\begin{array}{l}\text { Systolic blood pressure, } \\
\mathrm{mmHg}\end{array}$} & $121.9 \pm 14.4$ & $123.3 \pm 13.7$ & $118.9 \pm 15.3$ \\
\hline \multicolumn{2}{|c|}{$\begin{array}{l}\text { Diastolic blood pressure, } \\
\mathrm{mmHg}\end{array}$} & $78.3 \pm 10.8$ & $79.8 \pm 10.6$ & $75.0 \pm 10.5$ \\
\hline \multicolumn{2}{|c|}{ HDL cholesterol, mg/DI } & $50.9 \pm 11.6$ & $48.2 \pm 10.2$ & $56.7 \pm 12.4$ \\
\hline \multicolumn{2}{|c|}{ LDL cholesterol, mg/DI } & $116.8 \pm 31.8$ & $116.6 \pm 31.7$ & $117.1 \pm 31.9$ \\
\hline \multirow{2}{*}{\multicolumn{2}{|c|}{ Triglyceride, mg/DI }} & $143.8 \pm 96.5$ & $157.2 \pm 100.9$ & $114.9 \pm 78.9$ \\
\hline & & $\%$ & $\%$ & $\%$ \\
\hline \multirow[t]{2}{*}{ Smoking status } & Ex & 28.4 & 40.1 & 2.4 \\
\hline & Current & 27.0 & 37.4 & 3.8 \\
\hline \multicolumn{2}{|c|}{ Cardiovascular disease } & 41.9 & 44.7 & 36.1 \\
\hline \multicolumn{2}{|l|}{ Diabetes $^{a}$} & 9.0 & 10.2 & 6.3 \\
\hline \multicolumn{2}{|c|}{ Family history of diabetes } & 14.5 & 14.2 & 15.3 \\
\hline
\end{tabular}

SD standard deviation

${ }^{\mathrm{a}}$ Diabetes were defined as fasting serum glucose $\geq 126 \mathrm{mg} / \mathrm{dL}$ or medication

\section{Methods}

\section{Study population}

The participants were 4294 individuals who visited Health Examination Centers from 1994 to 2012 [15]. Among 4294 individuals, 1810 individuals were Cardiovascular Disease (CVD) cases identified by the health insurance reimbursement data from the NHIC. CVD was defined according to the International classification of Disease, Tenth Revision (ICD-10) (I00-I99). In total, 54 individuals were excluded due to missing fasting blood glucose levels and SNP rs5015480 data. The final subjects were 4240 individuals. Among 4240 individuals, 2461 individuals were healthy individuals, and the other 1779 individuals were Cardiovascular Disease (CVD) patients.

\section{Data collection}

The participants were interviewed using a questionnaire about smoking status and smoking amount. Self-reported alcohol consumption data were also collected from the questionnaire. Total cholesterol, high density lipoprotein cholesterol, low density lipoprotein cholesterol, triglyceride, and fasting blood sugar (FBS) were measured from blood samples obtained from each subjects after $12 \mathrm{~h}$ of fasting. Height and weight were measured with subjects lightly clothed. Detailed phenotypic data were previously described [15]. Diabetes was defined as fasting serum glucose $\geq 126 \mathrm{mg} / \mathrm{dL}$ or its management under medication.

\section{Genotyping assays}

The rs5015480 HHEX gene SNP was genotyped using the TaqMan reaction [16], with genotyping success rates of more than $98 \%$ and repeatability rates of more than $99 \%$.

\section{Statistical analysis}

Data are expressed as means \pm standard deviation. Most statistical analyses were performed using PLINK and SAS ver. 9.2 (SAS Institute, Cary, NC, USA). The linear regression under the additive genetic model was used to assess the association of HHEX rs5015480 with fasting blood glucose levels considering age and sex as covariates. We also used multiple logistic regression analysis under the recessive model to examine the combined effect of smoking on the relationship between HHEX rs5015480 and diabetes. Odds ratios (ORs) with 95\% confidence intervals (CIs) were calculated to investigate the relationship between HHEX SNP and diabetes. In the logistic model, we tested for interactions by assessing the statistical significance of the interaction term in models

Table 2 Association between the rs5015480 single nucleotide polymorphism in the HHEX gene and fasting blood sugar levels based on a linear regression model

\begin{tabular}{|c|c|c|c|c|c|}
\hline \multirow{3}{*}{ Phenotypes } & \multicolumn{5}{|l|}{ Genotypes } \\
\hline & $\pi$ & $\mathrm{TC}$ & $\mathrm{CC}$ & Effect & $P$-value \\
\hline & Mean \pm SD & Mean \pm SD & Mean \pm SD & ( $\beta)$ & \\
\hline All subjects & $(N=2827)$ & $(N=1278)$ & $(N=135)$ & & \\
\hline Fasting blood sugar, mg/dL & $96.5 \pm 21.7$ & $97.8 \pm 24.1$ & $100.1 \pm 28.1$ & 1.572 & 0.0122 \\
\hline Systolic blood pressure, mmHg & $121.6 \pm 14.0$ & $122.6 \pm 15.2$ & $121.6 \pm 14.9$ & 0.721 & 0.0676 \\
\hline Diastolic blood pressure, $\mathrm{mmHg}$ & $78.3 \pm 10.7$ & $78.5 \pm 11.1$ & $75.6 \pm 10.9$ & -0.341 & 0.2541 \\
\hline Healthy subjects & $(N=1672)$ & $(N=720)$ & $(N=69)$ & & \\
\hline Fasting blood sugar, mg/dL & $94.0 \pm 18.9$ & $95.9 \pm 21.8$ & $94.8 \pm 19.6$ & 1.420 & 0.0545 \\
\hline Systolic blood pressure, $\mathrm{mmHg}$ & $119.2 \pm 12.9$ & $119.9 \pm 13.8$ & $119.3 \pm 12.4$ & 0.544 & 0.2585 \\
\hline Diastolic blood pressure, $\mathrm{mmHg}$ & $78.7 \pm 10.8$ & $79.0 \pm 10.7$ & $76.9 \pm 10.0$ & -0.044 & 0.9103 \\
\hline
\end{tabular}

Estimated effect size ( $\beta$ ) and $p$-value in the multiple linear regression model considered age and sex in the additive model 
Table 3 Odds ratios (OR) of the polymorphic rs5015480 HHEX genotypes for diabetes ${ }^{\mathrm{a}}$ in the population

\begin{tabular}{|c|c|c|c|c|c|c|}
\hline \multirow{2}{*}{$\begin{array}{l}\text { Gene } \\
\text { SNP }\end{array}$} & \multirow[b]{2}{*}{ Subjects } & \multirow[b]{2}{*}{ Genotype } & \multirow{2}{*}{$\begin{array}{l}\text { Normal } \\
N(\%)\end{array}$} & \multicolumn{3}{|l|}{ Diabetes $^{c}$} \\
\hline & & & & $\overline{N(\%)}$ & $\mathrm{OR}\left(95 \% \mathrm{Cl}^{\mathrm{b}}\right)$ & $P$-value \\
\hline HHEX & All & Tा/TC & 3741 (96.9) & $364(95.8)$ & 1.00 (reference) & \\
\hline \multirow[t]{11}{*}{ rs5015480 } & $(n=4240)$ & $\mathrm{CC}$ & $119(3.1)$ & $16(4.2)$ & $1.44(0.83-2.48)$ & 0.1915 \\
\hline & Men & TТ/TC & 2509 (96.8) & 285(96.6) & 1.00 (reference) & \\
\hline & & CC & $83(3.2)$ & 10(3.4) & $1.10(0.56-2.17)$ & 0.7736 \\
\hline & Women & TТ/TC & 1232 (97.2) & 79(92.9) & 1.00 (reference) & \\
\hline & & CC & $36(2.8)$ & $6(7.1)$ & $2.68(1.05-6.82)$ & 0.0389 \\
\hline & All Healthy & & 2235 (97.2) & 157(97.5) & 1.00 (reference) & \\
\hline & $(n=2461)$ & CC & $65(2.8)$ & $4(2.5)$ & $0.82(0.29-2.31)$ & 0.7035 \\
\hline & Men & TT/TC & $1426(96.7)$ & 121(99.2) & 1.00 (reference) & \\
\hline & & CC & $48(3.3)$ & $1(0.8)$ & $0.24(0.03-1.73)$ & 0.1545 \\
\hline & Women & TT/TC & 809 (97.9) & $36(92.3)$ & 1.00 (reference) & \\
\hline & & CC & $17(2.1)$ & $3(7.7)$ & $4.46(1.15-17.3)$ & 0.0304 \\
\hline
\end{tabular}

${ }^{a}$ Adjusted for age and sex

${ }^{\mathrm{b}} \mathrm{Cl}$, confidence interval

'Diabetes were defined as fasting serum glucose $\geq 126 \mathrm{mg} / \mathrm{dL}$ or medication

that included the main effects. A two-sided significance level of $\alpha=0.05$ was used.

\section{Results}

The majority of subjects examined were middle-aged individuals (Table 1). Mean FBS level was significantly higher in males $(98.9 \mathrm{mg} / \mathrm{dL})$ than in females $(93.1 \mathrm{mg} / \mathrm{dL})$ $(p<0.0001)$. About $9.0 \%$ of the subjects were diabetes patients, and $14.5 \%$ of the subjects had a family history of diabetes. Of the sample dataset, $37.4 \%$ of males and $3.8 \%$ of females were current smokers, and $44.7 \%$ of males and $36.0 \%$ of females were cardiovascular disease patients. Table 2 indicates linear regression results, after adjusting for age and sex. The rs5015480 SNP in the HHEX gene was related to a mean FBS level (effect per allele, $1.572 \mathrm{mg} / \mathrm{dL}$, $p=0.0122$ ).

The relationship of the HHEX gene SNP rs5015480 with diabetes was examined (Table 3). Females with the CC genotype had a 2.68 times higher (range, 1.05-6.82-fold) risk of diabetes than those with the TT/TC genotype. For healthy individuals $(N=2461)$, the relationship was stronger in female subjects (OR, 4.46; 95\% CI, 1.15-17.3, $p=0.0304)$. In contrast, a relationship between HHEX and diabetes was not found in male subjects. The relation of the HHEX gene SNP rs5015480 with cardiovascular disease was also examined (Table 4). Females with the CC genotype had a 2.14 times higher (range, 1.05-6.80-fold) risk of cardiovascular disease than those with the TT/TC genotype.

The analysis according to smoking status in males is presented in Table 5. The relationship between HHEX and diabetes was much stronger in male heavy smokers (OR, 4.03; 95\% CI, 1.19-13.6, $p=0.0247$ ) than in non-smokers $(p=0.9709)$ and ex-smokers $(p=0.2399)$. Table 6 presents the age-adjusted odds ratios (ORs) for diabetes according to HHEX (rs5015480) genotype in strata of smoking status among Korean men. When compared with non-, ex-, or light smokers with the TT/TC genotype, the ORs (95\% confidence interval $(\mathrm{CI}))$ were $4.95(1.51-16.3)$ in heavy smokers having the $\mathrm{CC}$ genotype ( $\mathrm{P}$ for interaction $=0.0182$ ).

\section{Discussion}

In this study of 4240 individuals, the rs5015480 polymorphism in the HHEX was related to serum glucose level, which is similar to the results of previous studies. Our study found that HHEX polymorphism had a stronger relation to fasting glucose levels in women than in men. However, the interaction between sex and genotypic covariates was not significant $(\mathrm{p}$ for interaction $=0.1359)$ (Data not shown). A study in Korea also reported that the HHEX rs5015480 polymorphism was associated with the risk of diabetes in women $(p<0.005)$, but not in men $(p>0.005)$

Table 4 Odds ratios (OR) of the polymorphic rs5015480 HHEX genotypes for cardiovascular disease ${ }^{\mathrm{a}}$ in the population $(n=4240)$

\begin{tabular}{llllll}
\hline Subjects & & Normal & \multicolumn{4}{l}{ Cardiovascular Disease } \\
\cline { 4 - 6 } & Genotype & $N(\%)$ & $N(\%)$ & OR $\left(95 \% \mathrm{Cl}^{\mathrm{b}}\right)$ & $P$-value \\
\hline All & TT/TC & $2392(97.2)$ & $1713(96.3)$ & 1.00 (reference) & \\
& CC & $69(2.8)$ & $66(3.7)$ & $1.41(0.99-2.00)$ & 0.0607 \\
\multirow{2}{*}{ Men } & TT/TC & $1547(96.9)$ & $1247(96.6)$ & 1.00 (reference) & \\
& CC & $49(3.1)$ & $44(3.4)$ & $1.17(0.76-1.79)$ & 0.4735 \\
& TT/TC & $845(97.7)$ & $466(95.5)$ & 1.00 (reference) & \\
& CC & $20(2.3)$ & $22(4.5)$ & $2.14(1.12-4.10)$ & 0.0211 \\
\hline
\end{tabular}

${ }^{\text {a Adjusted for age and sex }}$

${ }^{\mathrm{b}} \mathrm{Cl}$, confidence interval 
Table 5 Odds ratios (OR) of polymorphic rs5015480 HHEX genotypes for diabetes ${ }^{\mathrm{a}}$ in Korean men $(n=2887)$

\begin{tabular}{|c|c|c|c|c|c|}
\hline \multirow[b]{2}{*}{ Subjects } & \multirow[b]{2}{*}{ Genotype } & \multirow{2}{*}{$\begin{array}{l}\text { Normal } \\
N(\%)\end{array}$} & \multicolumn{3}{|l|}{ Diabetes $^{c}$} \\
\hline & & & $N(\%)$ & OR $\left(95 \% \mathrm{Cl}^{\mathrm{b}}\right)$ & $P$-value \\
\hline \multirow[t]{2}{*}{ Non smokers } & ТT/TC & 533(97.3) & 68(97.1) & 1.00 (reference) & \\
\hline & $\mathrm{CC}$ & $15(2.7)$ & $2(2.9)$ & $1.03(0.23-4.67)$ & 0.9709 \\
\hline \multirow[t]{2}{*}{ Ex smokers } & ТT/TC & 958(97.2) & 113(99.1) & 1.00 (reference) & \\
\hline & CC & $28(2.8)$ & $1(0.9)$ & $0.30(0.04-2.24)$ & 0.2399 \\
\hline Light smokers & Tा/TC & 409(94.0) & $36(94.7)$ & 1.00 (reference) & \\
\hline (1-19/day) & CC & $26(6.0)$ & $2(5.3)$ & $0.83(0.19-3.69)$ & 0.8040 \\
\hline Heavy smokers & TT/TC & 452(97.8) & $50(92.6)$ & 1.00 (reference) & \\
\hline ( $\geq 20 /$ day) & CC & $10(2.2)$ & $4(7.4)$ & $4.03(1.19-13.6)$ & 0.0247 \\
\hline
\end{tabular}

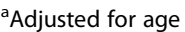

${ }^{\mathrm{b}} \mathrm{Cl}$, confidence interval

'Diabetes were defined as fasting serum glucose $\geq 126 \mathrm{mg} / \mathrm{dL}$ or medication

[10]. Another recent study suggested the association of the HHEX gene rs5015480 polymorphism with risk of gestational diabetes mellitus in women [17]. In this study, females with the CC genotype had a 2.14 times higher (range, 1.05-6.80-fold) risk of cardiovascular disease than those with the TT/TC genotype. However, an association between HHEX and cardiovascular disease was not found in male subjects.

Smoking is also highly related to type 2 diabetes [18-20]. In the present study, $37.4 \%$ of males and $3.8 \%$ of females were current smokers, which is similar to the results of Korean national data (44.6\% male and $4.6 \%$ female current smokers) [21]. We also found the association between the HHEX SNP and fasting glucose was stronger in heavy smokers than in nonsmokers. Some studies have reported that fasting glucose is regulated by smoking [22, 23]. A recent study reported that genetic polymorphism in glucagon may be modified by smoking for the risk of type 2 diabetes [22]. Another recent study reported that the AMPK $\alpha 1$ polymorphism may have the joint effects with cigarette smoking for the risk of coronary artery disease in the Chinese people [23]. A recent study also suggested interactions of well-known obesity-related polymorphisms with smoking [24].

HHEX encode homeobox transcription factors that are involved in organogenesis of liver and pancreas [17, 25]. A recent study reported that HHEX was related to insulin processing and secretion [4]. The frequency of rs5015480 C allele is 56.8\% in Europeans and 56.7\% in sub-Saharan Africans while the frequency in East Asians was $21.1 \%$ in Han Chinese in Beijing and $20.0 \%$ in Japanese, as shown in the HapMap data (NCBI website). Our study found a $\mathrm{C}$ allele frequency of $18.2 \%$.

In this study, the rs5015480 SNP was related to a mean FBS level $(p=0.0122)$. When the population is restricted to healthy subjects, the significant association was not found $(p=0.0545)$. One of the possible reasons for the difference is that the mean FBS level was lower in the healthy subjects $(94.6 \mathrm{mg} / \mathrm{dL})$ than in all subjects $(97.0 \mathrm{mg} / \mathrm{dL})$. This study has several other limitations. The available data do not allow us to classify participants by diabetes type. However, the proportion of type I diabetes in Korea is low, at $1 \%$ of diabetes cases [26]. In addition, we did not consider other major genes that contribute to type 2 diabetes susceptibility.

\section{Conclusion}

Genetic backgrounds in Western populations were different for Asian populations [27]. Thus, results of this study may not be generalized to all populations. However, our study showed that the HHEX gene on chromosome 10 is related to serum glucose levels in Korean women and male heavy smokers.

Table 6 Age-adjusted odds ratios (OR) for diabetes ${ }^{a}$ according to HHEX (rs5015480) genotypes in strata of smoking status in Korean men $(n=2887)$

\begin{tabular}{|c|c|c|c|c|}
\hline \multirow[b]{2}{*}{ Subjects } & \multirow{2}{*}{$\begin{array}{l}\text { No. of subjects } \\
\text { by genotypes }\end{array}$} & \multicolumn{3}{|l|}{ OR $\left(95 \% \mathrm{Cl}^{\mathrm{b}}\right)$} \\
\hline & & $\overline{\Pi T / T C}$ & CC & $P$ for interaction \\
\hline Smoking status & & & & 0.0182 \\
\hline Non/Ex/Light smokers & $2117 / 74$ & 1.00 (reference) & $0.65(0.26-1.64)$ & \\
\hline Heavy smokers & $502 / 14$ & $1.21(0.87-1.69)$ & $4.95(1.51-16.3)$ & \\
\hline
\end{tabular}

${ }^{\text {aAdjusted for age }}$

${ }^{\mathrm{b}} \mathrm{Cl}$, confidence interval 


\section{Abbreviations}

Cl: Confidence intervals; CVD: Cardiovascular Disease; FBS: Fasting blood sugar; GWAS: Genome-wide association studies; HDL: High density lipoprotein; HHEX: Hematopoietically expressed homeobox; ICD: International classification of Disease; LDL: Low density lipoprotein; OR: Odds ratios; SD: Standard deviation; SNP: Single nucleotide polymorphism

\section{Funding}

This research was supported by the Basic Science Research Program through the National Research Foundation of Korea (NRF) funded by the Ministry of Education, Science, and Technology (2015R1D1A1A01059651).

\section{Availability of data and materials}

The datasets used and/or analyzed during the current study available from the corresponding author on reasonable request.

\section{Authors' contributions}

Study design: JWS, SHJ. Subjects recruitment and acquisition of data: $\mathrm{SHJ}$ Analysis and interpretation of data: JWS, TYL, SHJ. Revision of manuscript content: all authors. Approving final version of manuscript: all authors.

\section{Ethics approval and consent to participate}

The Severance Medical Ethics Committee approved the study, and al participants provided written, informed consent prior to participation.

\section{Competing interests}

The authors declare that they have no competing interests.

\section{Publisher's Note}

Springer Nature remains neutral with regard to jurisdictional claims in published maps and institutional affiliations.

\section{Author details}

${ }^{1}$ Department of Biomedical Laboratory Science, College of Health Sciences, Eulji University, Seongnam, South Korea. ${ }^{2}$ Department of Preventive Medicine and Public Health, College of Medicine, Chungnam National University, Daejeon, Republic of Korea. ${ }^{3}$ Department of Epidemiology and Health Promotion, Institute for Health Promotion, Graduate School of Public Health, Yonsei University, Seoul, South Korea.

Received: 13 December 2017 Accepted: 19 April 2018

Published online: 02 May 2018

\section{References}

1. Unwin N, Shaw J, Zimmet P, Alberti KG. Impaired glucose tolerance and impaired fasting glycaemia: the current status on definition and intervention. Diabet Med. 2002;19(9):708-23.

2. Zeggini $E$, Weedon $M N$, Lindgren $C M$, Frayling $T M$, Elliott $K S$, Lango $H$, Timpson NJ, Perry JR, Rayner NW, Freathy RM, Barrett JC, Shields B, Morris AP, Ellard S, Groves CJ, Harries LW, Marchini JL, Owen KR, Knight B, Cardon LR, Walker M, Hitman GA, Morris AD, Doney AS, Wellcome Trust Case Control Consortium (WTCCC), MI MC, Hattersley AT. Replication of genomewide association signals in UK samples reveals risk loci for type 2 diabetes. Science. 2007;316(5829):1336-41.

3. Sladek R, Rocheleau G, Rung J, Dina C, Shen L, Serre D, Boutin P, Vincent D, Belisle A, Hadjadj S, Balkau B, Heude B, Charpentier G, Hudson TJ, Montpetit A, Pshezhetsky AV, Prentki M, Posner BI, Balding DJ, Meyre D, Polychronakos C, Froguel P. A genome-wide association study identifies novel risk loci for type 2 diabetes. Nature. 2007:445(7130):881-5.

4. Dimas AS, Lagou V, Barker A, Knowles JW, Mägi R, Hivert MF, Benazzo A, Rybin D, Jackson AU, Stringham HM, Song C, Fischer-Rosinsky A, Boesgaard TW, Grarup N, Abbasi FA, Assimes TL, Hao K, Yang X, Lecoeur C, Barroso I, Bonnycastle LL, Böttcher Y, Bumpstead S, Chines PS, Erdos MR, Graessler J, Kovacs P, Morken MA, Narisu N, Payne F, Stancakova A, Swift AJ, Tönjes A, Bornstein SR, Cauchi S, Froguel P, Meyre D, Schwarz PE, Häring HU, Smith U, Boehnke M, Bergman RN, Collins FS, Mohlke KL, Tuomilehto J, Quertemous T, Lind L, Hansen T, Pedersen O, Walker M, Pfeiffer AF, Spranger J, Stumvoll M, Meigs JB, Wareham NJ, Kuusisto J, Laakso M, Langenberg C, Dupuis J, Watanabe RM, Florez JC, Ingelsson E, MI MC, Prokopenko I, MAGIC Investigators. Impact of type 2 diabetes susceptibility variants on quantitative glycemic traits reveals mechanistic heterogeneity. Diabetes. 2014 Jun:63(6):2158-71.

5. Ali S, Chopra R, Manvati S, Singh YP, Kaul N, Behura A, Mahajan A, Sehajpal P, Gupta S, Dhar MK, Chainy GB, Bhanwer AS, Sharma S, Bamezai RN. Replication of type 2 diabetes candidate genes variations in three geographically unrelated Indian population groups. PLoS One. 2013;8(3):e58881.

6. Votsi C, Toufexis C, Michailidou K, Antoniades A, Skordis N, Karaolis M, Pattichis CS, Christodoulou K. Type 2 diabetes susceptibility in the Greek-Cypriot population: replication of associations with TCF7L2, FTO, HHEX, SLC30A8 and IGF2BP2 polymorphisms. Genes (Basel). 2017;8(1). https://doi.org/10.3390/genes8010016.

7. Han X, Luo Y, Ren Q, Zhang X, Wang F, Sun X, Zhou X, Ji L. Implication of genetic variants near SLC30A8, HHEX, CDKAL1, CDKN2A/B, IGF2BP2, FTO, TCF2, KCNQ1, and WFS1 in type 2 diabetes in a Chinese population. BMC Med Genet. 2010;11:81.

8. Zhou DZ, Liu Y, Zhang D, Liu SM, Yu L, Yang YF, Zhao T, Chen Z, Kan MY, Zhang ZF, Feng GY, Xu H, He L. Variations in/nearby genes coding for JAZF1, TSPAN8/LGR5 and HHEX-IDE and risk of type 2 diabetes in Han Chinese. J Hum Genet. 2010:55(12):810-5.

9. Wu Y, Li H, Loos RJ, Yu Z, Ye X, Chen L, Pan A, Hu FB, Lin X. Common variants in CDKAL1, CDKN2A/B, IGF2BP2, SLC30A8, and HHEX/IDE genes are associated with type 2 diabetes and impaired fasting glucose in a Chinese Han population. Diabetes. 2008;57(10):2834-42.

10. Ryoo H, Woo J, Kim Y, Lee C. Heterogeneity of genetic associations of CDKAL1 and HHEX with susceptibility of type 2 diabetes mellitus by gender. Eur J Hum Genet. 2011;19(6):672-5.

11. Foley AC, Mercola M. Heart induction by Wnt antagonists depends on the homeodomain transcription factor hex. Genes Dev. 2005;19(3):387-96.

12. Chen $G, X u Y$, Lin $Y$, Lai $X$, Yao J, Huang B, Chen Z, Huang H, Fu X, Lin L, Lai $\mathrm{S}$, Wen J. Association study of genetic variants of 17 diabetes-related genes/ loci and cardiovascular risk and diabetic nephropathy in the Chinese she population. J Diabetes. 2013;5(2):136-45.

13. Gupta V, Khadgawat R, Ng HK, Kumar S, Aggarwal A, Rao VR, Sachdeva MP. A validation study of type 2 diabetes-related variants of the TCF7L2, HHEX, KCNJ11, and ADIPOQ genes in one endogamous ethnic group of North India. Ann Hum Genet. 2010;74(4):361-8.

14. Estrada-Velasco BI, Cruz M, Madrid-Marina V, Martínez-Nava GA, GomezZamudio J, Burguete-García AI. IRS1, TCF7L2, ADRB1, PPARG, and HHEX polymorphisms associated with atherogenic risk in Mexican population. Biomed Res Int. 2013; https://doi.org/10.1155/2013/394523.

15. Cho ER, Jee YH, Kim SW, Sull JW. Effect of obesity on the association between MYL2 (rs3782889) and high-density lipoprotein cholesterol among Korean men. J Hum Genet. 2016:61(5):405-9.

16. Hui L, DelMonte T, Ranade K. Genotyping using the TaqMan assay. Curr Protoc Hum Genet. 2008 Jan;Chapter 2:Unit 2.10. doi: https://doi.org/10. 1002/0471142905.hg0210s56.

17. Tarnowski M, Malinowski D, Safranow K, Dziedziejko V, Czerewaty M, Pawlik A. Hematopoietically expressed homeobox (HHEX) gene polymorphism (rs5015480) is associated with increased risk of gestational diabetes mellitus. Clin Genet. 2017;91(6):843-8.

18. Jee SH, Foong AW, Hur NW, Samet JM. Smoking and risk for diabetes incidence and mortality in Korean men and women. Diabetes Care. 2010; 33(12):2567-72.

19. Kim SJ, Jee SH, Nam JM, Cho WH, Kim JH, Park EC. Do early onset and packyears of smoking increase risk of type II diabetes? BMC Public Health. 2014; 14:178. https://doi.org/10.1186/1471-2458-14-178.

20. Lyssenko V, Jonsson A, Almgren P, Pulizzi N, Isomaa B, Tuomi T, Berglund G, Altshuler D, Nilsson P, Groop L. Clinical risk factors, DNA variants, and the development of type 2 diabetes. N Engl J Med. 2008;359(21):2220-32.

21. Kim HS, Ro YJ, Kim NC, Yoo YS, Young JS, Oh JA. Prevalence and risk factors for diabetes mellitus and impaired fasting glucose of adults. J Korean Acad Nurs. 2000:30(6):1479-87.

22. Li L, Gao K, Zhao J, Feng T, Yin L, Wang J, Wang C, Li C, Wang Y, Wang Q, Zhai Y, You H, Ren Y, Wang B, Hu D. Glucagon gene polymorphism modifies the effects of smoking and physical activity on risk of type 2 diabetes mellitus in Han Chinese. Gene. 2014;534(2):352-5.

23. Ma X, Zhang J, Deng R, Ding S, Gu N, Guo X. Synergistic effect of smoking with genetic variants in the AMPKa1 gene on the risk of coronary artery disease in type 2 diabetes. Diabetes Metab Res Rev. 2014;30(6):483-8.

24. Ahmad S, Zhao W, Renström F, Rasheed A, Samuel M, Zaidi M, Shah N, Mallick NH, Zaman KS, Ishaq M, Rasheed SZ, Memon FU, Hanif B, Lakhani MS, 
Ahmed F, Kazmi SU, Frossard P, Franks PW, Saleheen D. Physical activity, smoking, and genetic predisposition to obesity in people from Pakistan: the PROMIS study. BMC Med Genet. 2015; https://doi.org/10.1186/s12881-0150259-x.

25. Tanaka T, Inazu T, Yamada K, Myint Z, Keng WW, Inoue Y, Taniguchi N, Noguchi T. cDNA cloning and expression of rat homeobox gene, hex, and functional characterization of the protein. Biochem J. 1999;339(Pt 1):111-7.

26. Kwon S, Lee JS. Study on relationship between milk intake and prevalence rates of chronic diseases in adults based on 5th and 6th Korea National Health and nutrition examination survey data. J Nutr Health. 2017;50(2):158-70.

27. Sung HJ, Jung MK, Eom Y, Lee J, Sull JW, Jee SH. Effects of MTNR1B variants on fasting glucose levels in a Korean population. Genes Genomics. 2012;34: 103-6.

Ready to submit your research? Choose BMC and benefit from:

- fast, convenient online submission

- thorough peer review by experienced researchers in your field

- rapid publication on acceptance

- support for research data, including large and complex data types

- gold Open Access which fosters wider collaboration and increased citations

- maximum visibility for your research: over $100 \mathrm{M}$ website views per year 